\title{
HUBUNGAN TINGKAT PENGETAHUAN KREDENSIALING KEPERAWATAN DENGAN MOTIVASI MENYELENGGARAKAN PRAKTTK MANDIRI MAHASISWA PROGRAM D III KEPERAWATAN DI SURAKARTA
}

\author{
Diyono', Shara Audia Nanda S. $^{2}$
}

\begin{abstract}
Kredensialing nursing encourages nurses apparently not motivated through independent practice. The number of nurses who carry out independent practice very few compared with the number of nurses in Indonesia. to know (1) the level of student knowledge about nursing kredentialing (2) The level of student motivation conducting independent practice (3) the relationship with the level knowledge of nursing kredentialing with motivation organize independent practice Student Nursing Program Diploma III in Surakarta.

Design of this research is correlational, with subjects study is 153 students of Diploma III of Nursing (76 from Surakarta Health Polytechnic and 77 from Panti Kosala Nursing Academy).

Results of this research are (1) Average knowledge level of nursing kredentialing is moderate,value of 15.89 (2) The level of motivation conducting independent practice nursing is 43.03 , moderate (3) There is a positive relationship between the level of knowledge about nursing kredensialing by organizing motivational practices independent in students Program D III of nursing in Surakarta 2016. The conclussion is a positive relationship, with a low level of correlation between the knowledge of credentialing nursing with motivation organize independent practice in students of Nursing Program Diploma III in Surakarta (p: 0.039;r:0.167)
\end{abstract}

Keywords: Nursing Kredentialing, Independent Nursing Practice

\section{PENDAHULUAN}

Praktik mandiri keperawatan merupakan wujud dari eksistensi keperawatan sebagai profesi mandiri. Praktik mandiri adalah praktik perawat di luar fasilitas pelayanan kesehatan (UU No. 38 Tahun 2014). Faktor utama sebagai latar belakang penelitian ini adalah karena masih minimnya perawat terutama perawat lulusan baru yang walaupun sudah memenuhi persyaratan, tetapi belum berani menyelenggarakan atau membuka praktik mandiri. Rata - rata mereka mengatakan aturan pemerintah sangat rumit sehingga malas untuk membuka praktik mandiri, dan lebih senang bekerja di fasilitas pelayanan kesehatan seperti rumah sakit atau puskesmas.

Secara umum kredensialing merupakan hal - hal yang berkaitan dengan lisensi, sertifikasi, akreditasi, dan registrasi. Kredensialing diperlukan untuk menjamin kualitas standar pelayanan praktik seorang perawat (Dermawan, 2013). Peraturan Menteri Kesehatan Nomor 17 tahun 2013, telah memberikan pijakan yang jelas bahwa perawat profesional dapat melakukan praktik mandiri sesuai dengan regulasi yang sudah ditentukan. Bahkan kesempatan untuk praktik mandiri perawat juga sudah diatur dalam sumber hukum yang lebih tinggi yaitu Undang Undang Republik Indonesia Nomor 38 Tahun 2014, dimana pada pasal 19 menjelaskan bahawa perawat diberikan izin untuk menyelenggarakan praktik mandiri. Regulasi tersebut secara jelas dan rinci telah memberikan payung hukum bagi perawat yang akan menjalankan praktik mandiri, sehingga semestinya perawat tidak 
perlu ragu - ragu lagi untuk berani melaksanakan praktik mandiri.

Fakta yang ada sekarang ini adalah setelah regulasi melalui program kredensialing keperawatan digulirkan, belum banyak perawat yang terdorong untuk melaksanakan praktik mandiri. Bukti empiris yang mendukung dugaan ini adalah penelitian dari Muhlisin (2014) yang membuktikan bahwa masih banyak perawat rumah sakit yag belum tahu tentang regulasi praktik mandiri, dan perawat yang sudah menjalankan praktik mandiripun, ternyata juga belum sesuai dengan regulasi yang sudah ada. Penelitian Syaiful (2015) juga memberikan hasil yang hampir sama, dimana dari seluruh perawat Kota Makasar, hanya ada 34 perawat yang menjalanan praktik mandiri, dan sebagian besar belum sesuai dengan kredensialing dan regulasi perundang - undangan yang berlaku. Hasil penelitian Ndruru (2012) yang meneliti tentang faktor - faktor yang berpengaruh terhadap praktik mandiri pada perawat di RS Paru Dr. Ario Wirawan Salatiga, menunjukkan bahwa motivasi merupakan salah satu faktor yang mempunyai pengaruh sangat kuat, selain kepercayaan diri, dan aspek legal praktik mandiri. Salah satu tujuan regulasi praktik mandiri perawat adalah untuk meningkatkan kesejahteraan perawat. Hal ini juga sesuai dengan hasil penelitian Tauhid, Margawati, dan Ardini (2015) yang memperlihatkan motivasi utama perawat membuka atau menyelenggarakan praktik mandiri adalah untuk meningkatkan penghasilan. Upaya atau usaha perawat menyelenggarakan praktik mandiri merupakan salah satu wujud kemandirian perawat sebagai profesi, dimana salah satu ciri profesi atau pekerjaan diakui sebagai profesi maka pekerjaan tersebut harus dapat dijadikan sebagai pekerjaan seumur hidup dan dapat menjadi sumber penghasilan utama (Kozier, et.al, 2007).

Berdasar uraian tersebut di atas, maka peneliti memandang perlu untuk melakukan penelitian tentang Hubungan Tingkat Pengetahuan Kredensialing Keperawatan dengan Motivasi Menyelenggarakan Praktik Mandiri pada Mahasiswa Program D III Keperawatan.

\section{TUJUAN PENELITIAN}

Secara umum penelitian ini bertujuan untuk mengetahui apakah ada hubungan antara tingkat pengetahuan tentang kredensialing keperawatan dengan motivasi menyelenggarakan praktik mandiri pada Mahasiswa Program D III Keperawatan di Surakarta. Sedangkan tujuan khususnya adalah untuk mengetahui tingkat pengetahuan mahasiswa Program D III Keperawatan di Surakarta tentang kredensialing keperawatan dan tingkat motivasi mahasiswa Program D III Keperawatan di Surakarta untuk menyelenggarakan praktik mandiri.

\section{METODE PENELITIAN}

Penelitian ini merupakan penelitian analitik dengan desain korelasional. Penelitian terdiri atas dua variabel, yaitu pengetahuan tentang kredensialing keperawatan sebagai variabel bebas atau variabel independen, dan motivasi praktik mandiri sebagai variabel terikat atau variabel dependen.

\section{POPULASI SAMPEL DAN TEKNIK SAMPLING}

Populasi pada penelitian ini adalah mahasiswa semester akhir program studi D III Keperawatan semester VI di Eks Karesidenan Surakarta. Melalui teknik sampling purposiv sampling sampel penelitian peneliti ambil dari mahasiswa 2 (dua) institusi Program D III Keperawatan, yaitu Akademi Keperawatan Panti 
Kosala Surakarta mewakili institusi swasta sebanyak 77 mahasiswa dan 76 responden dari Jurusan Keperawatan Politeknik Kesehatan Surakarta mewakili institusi pemerintah atau negeri.

Tingkat pengetahuan kredensialing peneliti ambil menggunakan tes kognitif, sedangkan data tentang motivasi menyelenggarakan praktik mandiri peneliti ambil dengan alat ukur kuesioner.

\section{HASIL PENELITIAN}

Pengetahuan Tentang Kredensialing Keperawatan

Tabel 1.

Distribusi Frekwensi Tingkat Pengetahuan Tentang Kredensialing Keperawatan

\begin{tabular}{ccc}
\hline Tingkat & $f$ & $\%$ \\
Pengetahuan & & 04 \\
\hline Tinggi & 7 & 90 \\
Sedang & 137 & 96 \\
Rendah & 9 & 06 \\
\hline Jumlah & 123 & 100 \\
\hline
\end{tabular}

Berdasar hasil penelitian sesuai tabel 1. memperlihatkan tingkat pengetahuan responden tentang kredesialing keperawatan paling banyak pada kategori sedang yaitu 137 atau 90\% sedangkan yang paling rendah adalah pada kategori tinggi yaitu hanya mencapai $04 \%$ atau senjumlah 7 responden.

Hasil analisa univariat tingkat pengetahuan mahasiswa D III Keperawatan di Surakarta Tahun 2016 tentang kredensialing keperawatan. Nilai rata - rata (mean) adalah 15,89 termasuk pada kategori sedang, nilai median adalah 16 termasuk kategori sedang, modus 18,00 termasuk kategori sedang. Untuk nilai paling tinggi adalah 24 termasuk kategori tinggi, minimal 8 kategori rendah, dengan standar deviasi 3,25.

Motivasi Menyelenggarakan Praktik Mandiri Keperawatan
Tabel 2.

Distribusi Frekwensi Tingkat Motivasi Menyelenggarakan Praktik Mandiri Keperawatan

\begin{tabular}{ccc}
\hline Tingkat & $\mathrm{f}$ & $\%$ \\
Motivasi & & 25 \\
\hline Tinggi & 39 & 74 \\
Sedang & 113 & 01 \\
Rendah & 1 & 100 \\
\hline Jumlah & 123 &
\end{tabular}

Tabel 2. menunjukkan motivasi mahasiswa program D III Keperawatan di Surakarta tahun 2016 untuk menyelenggarakan praktik mandiri paling banyak pada kategori motivasi sedang yaitu 113 atau $74 \%$ responden sedangkan yang paling sedikit adalah pada kategori motivasi rendah yakni 1 atau $1 \%$ responden.

Hasil analisa univariat untuk tingkat motivasi mahasiswa Program D III Keperawatan di Surakarta Tahun 2016 menyelenggarakan praktik mandiri keperawatan menunjukkan nilai rata - rata 43,03 termasuk pada kategori motivasi sedang, nilai median dan modus sama yaitu 42 juga termasuk kategori sedang. Adapun untuk nilai tertinggi adalah 57 termasuk kategori tinggi dan terendah adalah 30 termasuk kategori rendah, dengan standar deviasi 5,53.

Hubungan Tingkat Pengetahuan Tentang Kredensialing Keperawatan dengan Motivasi Menyelenggarakan Praktik Mandiri Keperawatan

Seperti terlihat pada tabel 3 . diperoleh hasil uji statistik Pearson Correlation dengan program SPSS for Windows seri 18 adalah 0,039 lebih kecil dari 0,05 yang berarti terdapat hubungan antara tingkat pengetahuan tentang kredensialing keperawatan dengan motivasi menyelenggarakan praktik mandiri keperawatan pada mahasiswa Program D III Keperawatan di Surakarta Tahun 2016, dengan 
tingkat kekuatan hubungan lemah $(r=0,167)$.

Tabel 3.

Hasil Pearson Correlatioan

Hubungan Tingkat Pengetahuan

Kredensialing Keperawatan dengan

Motivasi Menyelenggarakan Praktik Mandiri Keperawatan

\begin{tabular}{|c|c|c|c|}
\hline & & $\begin{array}{l}\text { PENGE- } \\
\text { TAHUAN }\end{array}$ & $\begin{array}{l}\text { MOTI- } \\
\text { VASI }\end{array}$ \\
\hline \multirow{3}{*}{$\begin{array}{l}\text { PENGE- } \\
\text { TAHUAN }\end{array}$} & $\begin{array}{l}\text { Pearson } \\
\text { Correlation }\end{array}$ & 1 & $.167^{\star}$ \\
\hline & Sig. (2-tailed) & & .039 \\
\hline & $\mathrm{N}$ & 153 & 153 \\
\hline \multirow{3}{*}{ MOTIVASI } & $\begin{array}{l}\text { Pearson } \\
\text { Correlation }\end{array}$ & $.167^{*}$ & 1 \\
\hline & Sig. (2-tailed) & .039 & \\
\hline & $\mathrm{N}$ & 153 & 153 \\
\hline
\end{tabular}

*. Correlation is significant at the 0.05 level (2tailed).

Berdasar hasil tersebut dapat disimpulkan terdapat hubungan positip antara tingkat pengetahuan tentang kredensialing keperawatan dengan motivasi menyelenggarakan praktik mandiri keperawatan pada mahasiswa Program D III Keperawatan di Surakarta Tahun 2016, dengan kekuatan hubungan lemah.

\section{PEMBAHASAN}

Pengetahuan Tentang Kredensialing Keperawatan

Pengetahuan individu tentang suatu obyek merupakan tahapan awal terbentuknya sikap dan perilaku. Pengetahuan tentang kredensialing keperawatan juga merupakan tahapan awal untuk membentuk sikap dan perilaku perawat dalam melaksanakan praktik mandiri. Pengetahuan harus dimulai semenjak calon perawat duduk di bangku kuliah sehingga dapat betul - betul membuat calon perawat paham tentang regulasi dan kredensialing yang diberlakukan di profesi perawat. Namun program tersebut tidak selalu berjalan dengan baik. Hasil penelitian menunjukkan tingkat pengetahuan mahasiswa Program D III
Keperawatan di Surakarta tentang kredensialing keperawatan secara umum belum maksimal. Fakta ini terlihat dari tabel 1. dimana secara rata - rata termasuk kategori sedang, dimana dari 123 responden, 90\% atau 137 responden mempunyai pengetahuan kredensialing kategori sedang, $06 \%$ atau 9 responden kategori rendah, dan hanya 7 responden atau $04 \%$ yang termasuk kategori tinggi. Hasil analisa univariat juga memperlihatkan secara umum responden mempunyai tingkat pengetahuan tentang kredensialing keperawatan kategori sedang, yaitu mean atau rata - rata 15,89 , median 16 , modus 18,00 dengan nilai tertinggi 24 dan terendah 8.

Pengetahuan merupakan hasil dari tahu yang terjadi setelah individu melakukan pengindraan terhadap suatu objek tertentu. Sebagian besar pengetahuan manusia diperoleh melalui mata dan telinga. Pengetahuan atau kognitif merupakan domain yang sangat penting dalam membentuk tindakan seseorang (overt behaviour). (Notoatmodjo, 2007). Pada kurikulum D III Keperawatan Tahun 2006 sebagai acuan kurikulum mahasiswa semester akhir tahun 2016, terdapat mata kuliah keperawatan profesional pada semester III, dimana secara detail membahas tentang regulasi dan kredensialing keperawatan. Pengetahuan dapat diperoleh melalui proses belajar tersebut dimana mahasiswa akan dikenalkan pada suatu obyek yaitu proses regulasi dan kredensialing keperawatan sehingga obyek tersebut dapat ditangkap olah panca indera, disimpan di dalam otak atau memori dan menjadi suatu pengetahuan. Pengetahuan tiap mahasiswa tentunya sangat bervariasi, dari tinggi sampai rendah. 
Temuan tersebut di atas mirip dengan hasil penelitian dari Muhlisin (2014) yang membuktikan bahwa masih banyak perawat rumah sakit yag belum tahu tentang regulasi praktik mandiri, dan perawat yang sudah menjalankan praktik mandiripun, ternyata juga belum sesuai dengan regulasi yang sudah ada. Mayoritas perawat yang praktik mandiri hanya meneruskan usaha orang tua dan banyak yang belum punya ijin. Penelitian Syaiful (2015) juga memberikan hasil yang hampir sama, dimana dari seluruh perawat Kota Makasar, hanya ada 34 perawat yang menjalanan praktik mandiri, dan sebagian besar belum sesuai dengan kredensialing dan regulasi perundang - undangan yang berlaku. Hasil - hasil penelitian tersebut memberikan bukti bahwa regulasi dan kredensialing keperawatan belum sepenuhnya dipahami oleh anggota profesi perawat termasuk mahasiswa sebagai calon perawat di masa yang akan datang.

\section{Motivasi Menyelenggarakan Praktik Mandiri}

Hasil penelitian sebagaimana telihat pada tabel 2. menunjukkan motivasi mahasiswa program D III Keperawatan di Surakarta tahun 2016 untuk menyelenggarakan praktik mandiri paling banyak pada kategori motivasi sedang yaitu 113 atau $74 \%$ responden sedangkan yang paling sedikit adalah pada kategori motivasi rendah yakni 1 atau $01 \%$ responden. Hasil analisa univariat menunjukkan nilai rata rata 43,03 termasuk pada kategori motivasi sedang, nilai median dan modus sama yaitu 42 juga termasuk kategori sedang. Adapun untuk nilai tertinggi adalah 57 termasuk kategori tinggi dan terendah adalah 30 termasuk kategori rendah, dengan standar deviasi 5,53.

Secara umum, motivasi berarti sesuatu yang mendorong untuk berbuat atau beraksi. Motivasi adalah semua hal verbal, fisik, atau psikologi yang membuat seseorang melakukan sesuatu sebagai respon (Sunaryo, 2014).

Mahasiswa Program D III Keperawatan semester semester VI merupakan mahasiswa semester akhir program studi, sehingga pada umumnya mereka sudah mulai berpikir dan bahkan sudah menentukan dimana mereka akan praktik atau bekerja. Sesuai dengan kompetensi yang diperoleh serta regulasi dari pemerintah dan organisasi profesi maka perawat dapat bekerja di fasilitas kesehatan maupun praktik mandiri baik secara perorangan maupun kelompok. Praktik madiri merupakan pilihan untuk menambah penghasilan dan kesejahteraan sebagai wujud kemandirian profesi. Hasil penelitian ini sejalan dengan hasil penelitian Ndruru (2012) yang meneliti tentang faktor - faktor yang berpengaruh terhadap praktik mandiri pada perawat di RS Paru Dr. Ario Wirawan Salatiga, menunjukkan bahwa motivasi merupakan salah satu faktor yang mempunyai pengaruh sangat kuat, selain kepercayaan diri, dan aspek legal praktik mandiri. Hal ini juga sesuai dengan hasil penelitian Tauhid, Margawati, dan Ardini (2015) yang memperlihatkan motivasi utama perawat membuka atau menyelenggarakan praktik mandiri adalah untuk meningkatkan penghasilan. Faktor pendorong utama yang memotivasi mahasiswa mempunyai keinginan untuk membuka atau menyelenggarakan praktik mandiri adalah untuk memperoleh tambahan pendapatan dan meningkatkan kesejahteraan. Hasil ini sesuai dengan penelitin Tauhid, Margawati, dan Ardani ( 2015) yang berjudul Pengalaman Perawat dalam Membuka Praktik Mandiri Keperawatan di Kabupaten Badung Provinsi Bali, dimana 
melalui penelitian kualitatif terhadap 5 perawat yang menyelenggarakan praktik mandiri yang ditriangulasi dengan ketua PPNI Kabupaten Badung dan 3 pasien, menunjukkan bahwa motivasi utama perawat menyelenggarakan praktik mandiri adalah menambah pendapatan atau penghasilan.

Hubungan Tingkat Pengetahuan Tentang Kredensialing Keperawatan dengan Motivasi Menyelenggarakan Praktik Mandiri Keperawatan Hasil penelitian sebagaimana terlihat atau ditunjukkan pada tabel 3. memperlihatkan berdasar hasil uji statistik Pearson Correlation dengan program SPSS for Windows seri 18 dapat disimpulkan terdapat hubungan positip antara tingkat pengetahuan tentang kredensialing keperawatan dengan motivasi menyelenggarakan praktik mandiri keperawatan pada mahasiswa Program D III Keperawatan di Surakarta Tahun 2016, dengan kekuatan hubungan lemah. Dengan kata lain hasil penelitian ini memberikan bukti bahwa semakin tinggi pengetahuan mahasiswa tentang kredensialing keperawatan, maka semakin tinggi pula motivasi mahasiswa untuk menyelengarakan praktik mandiri keperawatan. Pengetahuan adalah hasil tahu terhadap suatu obyek setelah individu memperoleh stimulus pada panca indranya. Menurut Notoatmodjo (2007), tingkatan pengetahuan dalam domain kognitif mempunyai 6 tingkat, meliputi tingkatan tahu (know), memahami (comprehension), aplikasi (Application), analisis (Analysis), sintesis (synthesis), dan evaluasi (evaluation). Sesuai tingkatan tersebut, maka seseorang dalam hal ini mahasiswa program D III Keperawatan setelah memperoleh informasi suatu obyek yaitu proses kredensialing, manfaat praktik mandiri, keuntungan praktik mandiri, regulasi praktik mandiri dan sebagainya, maka akan diolah dalam memori untuk mencapai memori atau kognitif sesuai dengan tingkatan masing - masing. Secara umum sesuai hasil penelitian ini memperlihatkan, semakin tinggi tingkat pengetahuan mahasiswa tentang kredensialing dan praktik mandiri, maka akan semakin tinggi juga keinginan atau motivasi mahasiswa untuk di kemudian hari akan menyelenggarakan praktik mandiri keperawatan.

Menurut Whitehead, Weiss, dan Tapen (2010), salah satu faktor yang mempengaruhi motivasi adalah pemahaman terhadap suatu obyek. Pengetahuan ini akan memotivasi seseorang, yang dikenal dengan motivating by identification atau ego-involvement atau memotivasi dengan menanamkan pengetahuan dan kesadaran sehingga individu berbuat sesuatu karena adanya keinginan yang timbul dari dalam dirinya sendiri. Dalam hal ini dapat dianologikan bahwa jika mahasiswa sudah memahami tentang maksud dan tujuan kredensialing dan keuntungan atau kelebihan praktik mandiri keperawatan maka akan muncul dalam dirinya untuk berani memilih menyelenggarakan praktik mandiri keperawatan.

Hasil penelitian ini juga menunjukkan kalau pengetahuan merupakan salah satu komponen yang mempengaruhi motivasi seseorang. Dalam hal ini pengetahuan mahasiswa tentang kredensialing mempunyai peran dalam meningkatkan motivasi atau keinginan mahasiswa setelah lulus untuk menyelenggarakan praktik mandiri. Konsep motivasi menurut Nursalam (2011) tersebut sesuai dengan hasil penelitian ini, dimana faktor - faktor yang memotivasi mahasiswa untuk menyelengarakan praktik mandiri sangatlah bervariasi, seperti adanya keluarga yang 
berprofesi sebagai perawat, pemahaman tentang kelengkapan surat untuk praktik mandiri, dan keberadaan keluarga yang menyelenggarakan praktik mandiri.

Berdasar nilai koefisien korelasi dari uji statistik yaitu positip 0,167 menunjukkan tingkat hubungan atau korelasi yang rendah. Hasil ini dapat dimungkinkan karena ada faktor faktor lain yang mempengaruhi motivasi mahasiswa untuk menyelenggarakan praktik mandiri keperawatan, selain faktor tingkat pengetahuan tentang kredensialing keperawatan. Hal ini sesuai dengan hasil jawaban kuesioner yag penulis sebarkan, menunjukkan ada faktor faktor lain yang mendorong atau memotivasi mahasiswa untuk meyelenggarakan praktik mandiri, yaitu faktor keluarga dan role model praktik mandiri yang dilakukan oleh keluarga dari responden, mempunyai motivasi lebih tinggi dari pada yang tidak, yaitu $72 \%$ berbanding $28 \%$.

Hasil ini sejalan dengan hasil penelitian dari Ndruru (2012) yang meneliti tentang faktor - faktor yang berpengaruh terhadap praktik mandiri pada perawat di RS Paru Dr. Ario Wirawan Salatiga, menunjukkan bahwa motivasi merupakan salah satu faktor yang mempunyai pengaruh sangat kuat, selain kepercayaan diri, dan aspek legal praktik mandiri.

Hasil penelitian terdahulu mengenai kaitan pengetahuan dengan motivasi yang juga mendukung hasil penelitian ini adalah penelitian dari Koro (2014) yang berjudul Faktor yang Berhubungan dengan Kinerja Perawat di Unit Rawat Inap RSUD Lamaddukelleng Kabupaten Wajo Tahun 2014. Walaupun penelitian tersebut sedikit berbeda dalam varibel terikat, namun memberikan gambaran yang hampir sama mengenai hubungan pengetahuan dengan motivasi. Hasil penelitian tersebut membuktikan bahwa terdapat hubungan yang bermakna antara pengetahuan dengan motivasi terhadap kinerja perawat, dimana nilai $p<0,005$ yaitu 0,002 dan 0,004 . Hasil tersebut menambah fakta bahwa terdapat hubungan antara pengetahuan individu terhadap obyek atau topik tertentu dengan motivasi melakukan tindakan atau perilaku termasuk dalam penelitian ini adalah motivasi menyelenggarakan praktik mandiri keperawatan.

\section{KESIMPULAN}

1. Secara umum pengetahuan mahasiswa Program D III Keperawatan di Kota Surakarta Tahun 2016 tentang kredensialing keperawatan , termasuk kategori sedang, dengan nilai rata - rata 15,89.

2. Tingkat motivasi mahasiswa Program D III Keperawatan di Kota Surakarta Tahun 2016 untuk menyelenggarakan praktik mandiri keperawatan secara umum adalah kategori sedang dengan nilai 43,03 .

3. Pengetahuan tentang kredensialing keperawatan mempunyai korelasi positip dengan motivasi menyelenggarakan praktik mandiri pada mahasiswa keperawatan Program D III Keperawatan di Kota Surakarta Tahun 2016 (Pearson Correlation p : 0,039 dan $r: 0,167)$.

\section{SARAN}

1. Institusi pendidikan Program Diploma III Keperawatan diharapkan terus meningkatkan pengetahuan mahasiswa tentang kredensialing keperawatan.

2. Regulasi praktik mandiri keperawatan diharapkan terus disosialisasikan kepada mahasiswa untuk menambah wawasan mahasiswa tentang praktik mandiri.

3. Organisasi profesi diharapkan dapat meningkatkan sosialisasi 
mengenai kredensialing keperawatan dan praktik mandiri, melalui perbaikan kurikulum, kegiatan workshop ataupun seminar.

\section{DAFTAR PUSTAKA}

Dermawan, D. 2013. Pengantar Keperawatan Profesional. Gosyen Publising, Yogyakarta.

Dewan Pengurus Pusat (DPP) PPNI. 2014. Naskah Akademik Undang-Undang Keperawatan. Jakarta. www.inna.-PPNI.co.id. Diunduh 04 April 2016

Druru, F. 2012. Faktor - Faktor yang Mempengaruhi Praktik Keperawatan Mandiri.http://repository.uksw. edu/bitstream/123456789/202 5/1/xT1.462007060_Judul. Diunduh 03 April 2016.

Kemenkes RI. 2013. Keputusan Menteri Kesehatan Republik Indonesia Republik Indonesia No. 17 Tahun 2013 Tentang Perubahan Atas Peraturan Menteri Kesehatan Republik Indonesia No. 148 Tahun 2010 Tentang Izin dan Penyelenggaraan Praktik Perawat.

Koro, I. P. 2014. Faktor yang Berhubungan dengan Kinerja Perawat di Unit Rawat Inap RSUD Lamaddukelleng Kabupaten Wajo Tahun 2014. http://repository.unhas.ac.id/bit stream/handle/123456789/108 77/itapurnamasariKaro\%20K1 1108\%20978.pdf;sequence=1. Diunduh 04 April 2016.

Kozier, B., et al. 2007. Praktik Keperawatan Profesional (Konsep dan Perspektif). Alih bahasa. Yuyun Yuningsih, Nike Budhi Subekti. EGC, Jakarta.
Muhlisin. Pembinaan Dan Pengawasan Penyelenggaraan Praktik Mandiri Perawat Di Kota Salatiga. Yogyakarta, 2014. URLhttp://etd.repository.ugm.a c.id/index.php?mod=penelitian _detail\&sub=PenelitianDetail\&a ct=view\&typ=html\&buku_id=69 924. Diakses/Diunduh tanggal 17 Oktober 2015.

Nursalam. 2011. Manajemen Keperawatan : Aplikasi Dalam Praktik Keperawatan Profesional. Edisi III. Salemba, Jakarta.

Notoatmodjo, S. 2007. Promosi Kesehatan dan IImu Perilaku. Rineka Cipta, Jakarta.

Sunaryo. 2014. Psikologi untuk Keperawatan. EGC, Jakarta.

Syaiful. 2015. Fungsi dan Peran Perawat dalam Menyelenggarakan Praktik Mandiri di Kota Makasar.http://repository.unha s.ac.id:4001/digilib/files/disk1/ 401/--syaiful-20036-1-15-syaif\%29.pdf. Diunduh 04 April 2016.

Undang - Undang RI No. 38 Tahun 2014 Tentang Keperawatan.

Tauhid, Margawati A., dan Ardani M.H. 2015. Pengalaman Perawat dalam Membuka Praktik Mandiri Keperawatan di Kabupaten Badung Provinsi Bali.http://eprints.undip.ac.id/4 7207/1/. Diunduh 05 April 2016.

Whitehead, Weiss, dan Tapen. 2010. Essential of Nursing Leadership and Management. Fifth Edition. Davis Company, Philadephia.

${ }^{1}$ Dosen Akper Panti Kosala

Surakarta

${ }^{2}$ Mahasiswa Akper Panti Kosala

Surakarta 